\title{
Aphorisms in Multi-Camera Television Production Education
}

\author{
Robert Gordon Jr. \\ Assistant Professor \\ Phone: $615-898-5862$ \\ Cell: $615-828-5782$ \\ Linkedln: https://www.linkedin.com/in/gordontv \\ Facebook: http://www.facebook.com/bob.gordon.GTG615 \\ Twitter: @bobgordontv
}

Electronic Media Communication Department, College of Media and Entertainment

Middle Tennessee State University, PO 58, Murfreesboro, Tn 37132, USA

\author{
Article Info: \\ Received 12 February 2016 \\ Accepted 1 April 2016 \\ Published 23 August 2018 \\ DOI: https://doi.org/10.12973/ojemt/3833
}

Many University media production programs provide a variety of cinema-based production classes. Teaching live, special-event, multi-genre, multi-camera television production is very different. This paper presents a variety of insights, orientations and sensitivities for providing inspiring and practical multi-camera instruction.

Keywords: aphorisms, multi-camera television, production education

Multi-camera television production has been a part of our lives since the first, threecamera presentation of the one-act, melodrama, "The Queen's Messenger", on September 28, 1928.

Since then, we have all enjoyed a wide array of drama, comedy, sporting events, music, news, game shows as produced live, with a multitude of cameras. The platforms and technologies change but the basic genres have stayed the same.

We no longer live in a three-network world with a narrow creative funnel through which ideas, concepts, scripts and pilots must pass. Never before have there been so many viewing options, produced by so many with equipment so powerful and so affordable.

I am a professional television producer who teaches multi-camera program production at the University level. For forty one years, I have been fortunate to have produced, managed or directed a wide array of programming for broadcast and cable networks, broadcast stations, syndication and home video release, For the past eight years, I have also been teaching multicamera program production at Middle Tennessee State University.

Often, the student is equal-parts fascinated with and intimidated by the technology involved in producing live television. It is a complex task to combine ever-changing technical knowledge, logistical management, market analysis, team management, lightening-fast decisionmaking, aesthetic concepts and ...show business.

At the "College of Media and Entertainment" at MTSU, I teach three levels of multi-camera television production. 
"Introduction to Studio Production" is a Sophomore-level course where the basics of lenses, camera composition and operation, audio production, switchers, record and playback devices and studio operation are taught. In addition to bookwork and lecture and demonstrations, the class is broken up into several once-a-week labs where the students get hands-on time and their first opportunity to team up to produce short in-studio interview or demonstration segments.

The next class in the sequence is "Multi-camera Producing and Directing." This is a labintensive class where students are taught to direct newscasts, cooking shows and music performances. In addition to gear-training, much time is spent teaching the organization and operation of production teams. They learn how to direct script and time-focused productions (newscasts), unscripted yet formatted programs (cooking shows) and scripted, musical performance pieces where an aesthetic sense has to come into play.

The last level of classes are advanced classes. One semester is a sports event production class where students manage, produce direct and crew up to 27 live Women's Volleyball and Soccer matches on C-USA website, goblueraider.com website and the county-wide, student-run cable channel, MT10.

These are 9 camera, 7 replay, graphic-heavy, sporting-events that are all unrehearsed, live, and produced in one-take.

In the spring semester, I teach a live concert production class, where we again take our $\$ 1.75$ million dollar, 9 camera HD truck and record a variety of live concert events ranging from the Nashville Symphony to live, multi-act Capitol Records artist events to 300,000-visitor music festivals like the Bonnaroo Music and Arts Festival.

In both cases, students learn program production management, conceptual development, team building, communication, rapid problem solving skills, production-design and program production.

This whole arc takes place in 3 semesters. 45 weeks. It's a fast, intense path. Some students choose to go in other directions but many have become professionals before they graduate our program. Many are on tour with national performing acts. Others regularly crew professional network sports.

In my eight years teaching production at the University level, I have noticed that I say many of the same things, "Universal Truths", in my mind.

An "Aphorism" is defined as being a concise statement of a principle, embodying a general truth, or an astute observation.

I use the following in my classes and offer them for your use and/or amusement.

\section{"TV does not reward the meek"}

I stress students to be proactive, to be energetic, to try, to step forward, to raise their hands and volunteer. Multi-cam program production takes force of will and leadership skills to direct a large group of people to use technology, logistics and manpower to convert an idea into a completed project. Some students are pro-active, some recede into the shadows. In a professional world, which is mostly freelance, students must take charge of their idea and their production role. There are far more people looking for production jobs than there are production jobs. A successful student must develop a pro-active, confident, active approach. I encourage it regularly.

\section{"Produce your position"}

There are no small jobs. Some students underappreciate the importance of "small jobs" such as cable grip or prompter operator or the wide-shot camera. I spend much time stressing that at some point, even the most unexciting role takes center-stage. Every time the wide-shot game camera is taken, as it pans back and forth across the court, it becomes the entire show. The moment a live hand-held camera operator trips or gets hung up on-air, the cable grip gets all the attention. 
Instead of looking at their role as an equipment operator, I stress for the students to look at themselves as "producing" that job. How that shot is composed, how fast a font is called up, how quickly a replay video is cued up should be the result of a student being creatively and operationally in charge of that part of the program. They should not just be the one who pushes a button.

\section{"What time does the 6 o'clock News start?"}

This is one of the first questions I ask students in my "Introduction to Studio Production" class. They all think it must be a trick question and hesitate to answer. After pausing, I say "Six o'clock. Six hours, 0 minutes, 0 seconds, 0 frames. Not 10 seconds before 6 or 4 seconds after 6 but 6 .... period”.

I stress that live television program production is probably the most time-focused and timeconstrained human activity on Earth. They need to respect and follow time deadlines - now. If a show is to end at 6:28:45, it will or Master Control cuts to a commercial in the middle of your big finale. If the producer plans for a 1:30 package, it has to be one minute and thirty seconds. Time rules in TV.

\section{"Don't be destined for food service"}

TV is not for everyone. I say early on that not everyone has the personality, focus, concentration or pressure-coping skills for live TV. Those that miss class, miss assignments, miss projects, or bail on their production partners are not going to have a career in the field.

In a freelance-intensive world, one can move from the "Call List" to the "Do Not Call" list in an instant and may never be told why. It is often really difficult to come back.

\section{"Everything is temporary"}

TV production is a very fluid enterprise. People ebb and flow from one production to the next and often their roles change. One can be a network executive one day and then become a freelance associate producer the next. One can be a production assistant one day and become an associate producer the next. It goes both ways. I often tell students that entry-level gofer jobs are not beneath them. "Every big shot was a 'no shot' at some point."

I tell students that they will not stay a "gofer" for very long in a production. They will either prove they are too valuable to stay as a "gofer" and get promoted or they will prove they can't even copy scripts right and they are let go. Everything is temporary.

\section{"The power to lead is granted by the lead"}

I learned this lesson early on. Often people think that an inspiring leader has some kind of magical power over their staff, or they have some frightening power over them. The inverse is really true. One can only lead a group of people, when they chose to be lead by the one. The power to follow comes from the follower. To lead, one must serve.

\section{"3 rules for success - just show up, do what you are asked, be pleasant"}

This is another line I use the first day of class. I ask if everyone would like my 3 rules for success. Their ears perk up. I then simply say... "Just Show Up. Do what you are asked to do and be pleasant to work with." Before they give a collective "Duh", I reveal that many people can't accomplish those 3 rules and as a result have a less than a stellar path.

A producer or production manager just wants you to NOT be a problem for them. Don't be the one who people ask, "Where is he/she?" Your presence shows your commitment. Your presence also allows you to get a new job because ...someone else didn't show. 
Do the job you are hired for. Don't talk about what you really want to do. You were hired to do something specific. If you aren't doing it, someone else will have to or you will have to be "supervised" and usually production managers don't want to bother. It is easier to replace you than to follow up on you.

Finally, be pleasant. There are loads of creative, talented people in the world and some are not fun to be around. Usually people would prefer to work with a competent, fun person than a genius who is a pain in the butt.

\section{"You only really fail when you quit"}

I try to stress that responses such as "No thanks", "Not Now", "We're Going to Pass", "We Can't Afford It Right Now", "We already Have One" are things we often hear. Everyone turned George Lucas down with his space opera script. You don't fail when you hit a wall or an obstacle. You fail when you stop.

Having a project crash and burn is not a failure. It is usually the best teacher. I tell students that I FAR more vividly remember my crashes than I do my successes. I learned to "never do THAT again." Having a bad show or a rejected pitch is not a failure. It is an obstacle, a lesson. Deciding to quit and not try again is a failure.

\section{"Nine out of ten deals die and no deal is ever dead."}

This is not really a Zen Koan. It is real life in the entertainment industry. There are million reasons why a deal or a proposal dies and most of them usually have nothing to do with you.

The network may already be doing a show like your idea but can't tell you. The studio might be out of budget at this moment. The exec might have tried to do something like your pitch and screwed it up but won't admit that to you. The agent you are presenting to might be on his way out and doesn't want you to know. The person you are proposing to might be a dolt but doesn't know it.

Every one of those might cause your show or idea to not be accepted and it had nothing to do with you.

So what do you do? You present to someone else. You make changes to your idea. You wait out the change or the creative weather and present again. You re-cast the idea. You cut the budget. You add to the budget. You bring in a partner. You bring in a star.... a million things. What you don't do is take it personally and quit. You bounce.

\section{"You have to be in the present and in the future at the same time."}

This is unique to live television directing. I stress to students that they have to give commands in this moment BUT, they have to be planning for the next moment and to look ahead to see if a camera died, or a wrong graphic is up or the talent fell over. You have to be directing people right now AND you have to preparing everyone for the next few steps - both at the same time.

The one place you can't be is in the past. You can't be rattled or angry or embarrassed or worried about what wrong thing that just happened. That's done. To focus on that just insures that three more mistakes are about to happen.

I often compare live TV directing to the Indiana Jones scene, where he steals the idol and a massive boulder rolls after him. I encourage student directors to stay ahead of the boulder or get run over. 
'Where are you going? What's next?"

Shot sequences are key in TV directing. I tell students that directing is just like editing except it is live and you have no second chance. Framing is the same, sequences are same, transitions are the same but you make those choices live, with people watching.

Often students take a shot and then feel like that was an accomplishment. They freeze or pause and wait to figure out where to go next. I am often behind them asking, "What's next? Where are you going?" I force them to be in the flow, make a decision, put it in the past file and go to the next place. I get them to think ahead.

Think in 3 or 4 shot sequences. If you are on shot $\mathrm{A}$ and need to get to shot $\mathrm{E}$ at a particular point of the song, or comedy bit, then what are shots B, C and D?

Don't think in terms of shots, think in terms of sequences of shots.

"Say what you want, don't think it"

Terminology is key. If you want a dissolve, say, "Dissolve". If you want a take, say, "Take". If you are not specific, then your crew has to waste time and security trying to guess what you mean rather than follow what you say.

Why should the viewer care about what you made?"

Viewers have more choices now than ever. Besides having hundreds of cable choices, they have broadband, mobile and mp3 players. They are often doing/watching/ listening/typing several things at once. They no longer have to walk across the room to change a channel. Viewing choices are made in a couple of seconds, if that.

Producers need to answer the question "Why should a viewer care about this? Why should they pick me? Why should they stay with me? Why should they come back? Why should they tell their friends to sample me?"

Think in terms of the viewers' needs, not your own.

"Creative' camera work is not the same as "active" camera work."

In a concert production class of mine, I had a student operating a handheld camera. His role was to focus on a keyboardist from stage right and to shoot a reverse angle of the vocalist and the crowd. He was disappointed that he only had two shots and he wanted to be able to get on stage and get in around the musicians and do "dutch angles" and high angle shots. He wanted "to be creative".

I reminded him that he has specific shots that only he can get and they are important. To be in and around the musicians either puts him in the shot or blocks other cameras. I also reminded him that the goal is present the performer not to entertain himself.

He confused being "creative" with being "active". He wanted to zoom and focus and move around which is not always being creative. It's pushing buttons. Students must remember their job is to help tell the story that the PERFORMER is telling.

"You are a part of the camera team, not the whole camera team."

I run into this often with students with single-camera experience. In the single-camera world, the camera operator has to shoot everything that moves to get coverage. In multi-cam, the operator has to shoot just the elements that he is assigned. We don't need 5 wide shots or 4 close ups of the singer. It takes some time to explain the function of each camera and how it blends and connects with all the other cameras. 
"What is your Plan A, Plan B, Plan C?"

In Live TV, Murphy's Law always rules. If it can go wrong, it will. Plan for it. Students don't want to fail and they feel doing something over again is a failure. They are used to doing an assignment and not have the world collapse around them. I spend a lot of time role-playing with students. "What do you do if your wide-shot camera dies?" "What's your power backup?". "What do you do if a performer is getting ill and might not be able to perform in slot that you have planned for her?" What do you do if the video file for your open won't play?

Never assume your initial plan will work flawlessly. Have contingencies for everything.

"A producer's job is to make a viewer feel a certain way in order to make them do a certain thing."

Whether it is a newscast or a basketball game or a political ad or a music video or a commercial, these items exist for one thing, ultimately... to motivate you to buy or vote or recommend or imitate something. People are not motivated to do anything unless they are inspired emotionally or imaginatively to do so.

For better and for worse, every visual product is made to motivate some kind consumer action. To meet that goal, creative people need to know their audience, know their sponsor's/client's goals, understand aesthetics and psychology and be very current with technology. Who do you want to effect?" What do you want them to do? What creative approach will make that happen?" What tools and techniques do you need to use? Think from the outside in. Thinking from the inside out might please you but might leave the client unsatisfied and the viewer bored.

\section{Summation}

Every semester, I receive a new batch of students and the aphorisms come out again. They may be new to the students but they are well-worn to me. I am usually bolstered when I have a guest lecturer from the professional world come to class who says many of the same things that I do. (It has been said that an "expert" is anyone from 500 miles away). We all come from different sources and are approaching different destinations but our paths seem to be very much the same.

I had a former student come to guest lecture one time. He has a great professional experience since his recent graduation but he is closer in age to my students than I am. After he began his talk, 3 students came in late and one was texting on his phone.

My former student stopped, pointed to the three tardy students and said, "If this were the professional world, I would not hire you, you and you. You are either on time or you're out." He then looked to the student texting on his phone and said, "And I would fire you. Your job here now is to listen and learn, NOT play with your phone."

I grinned. Lessons learned and now re-taught.

Different people, Different skills. Different experiences. Universal truths.

Aphorisms in Multi-camera.

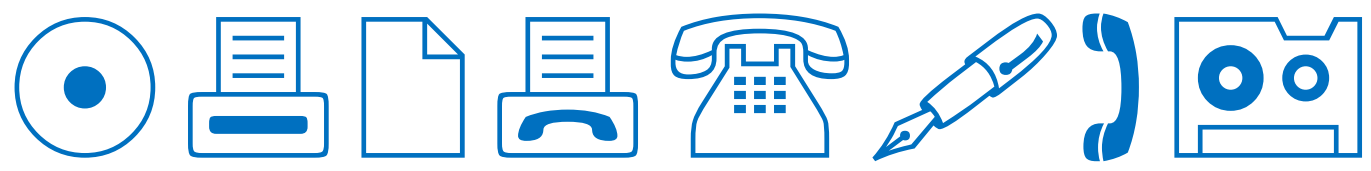

